\title{
SCIENTOMETRIC ANALYSIS OF QUARTERLY JOURNAL OF INDIAN JOURNAL OF ANIMAL NUTRITION (IJAN)
}

\author{
Rajendran Lakshmanan ${ }^{1} 凹$ (iD) \\ ${ }^{1}$ Assistant Librarian, Department of Library Science, Madras Veterinary College, Tamil Nadu Veterinary and \\ Animal Sciences University, Chennai, Tamil Nadu, India.
}

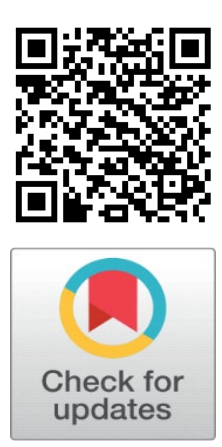

\section{ABSTRACT}

Using scientometric analysis, animal nutrition research from 2016 to 2020 was collected from the quarterly journal of the Indian Journals of Animal Nutrition. According to the research, 384 papers were written between 2016 and 2020, with 24 papers being highly published in 2016. As a result, animal nutrition is the most popular topic among scientists interested in veterinary research, with 1838 papers published out of 384. In particular, author Chander Data published 15 publications in the years $(2016,2017,2018$, and $2020)$, and some authors published $(2,3,4,5,6,7,8,9,10,11,12)$ articles in the years $(2016$, 2017, 2018, and 2020).

Received 2 September 2021

Accepted 16 September 2021

Published 30 September2021

\section{CorrespondingAuthor}

Rajendran Lakshmanan,

rajendranlak@yahoo.com

DOI

10.29121/granthaalayah.v9.i9.2021. 4245

Funding: This research received no specific grant from any funding agency in the public, commercial, or not-for-profit sectors.

Copyright: (C) 2021 The Author(s). This is an open access article distributed under the terms of the Creative Commons Attribution License, which permits unrestricted use, distribution, and reproduction in any medium, provided the original author and source are credited.
Keywords: Scientometric, Indian Journals, Animal Nutrition, Relative Growth Rate, Doubling Time

\section{INTRODUCTION}

Original papers on research in the fields of animal nutrition, feed technology, feed evaluation and conservation, physiological and biochemical aspects including microbiology, biotechnology, feed and feeders, and other relevant areas related to livestock feeding in developing and tropical regions are published in the Indian Journal of Animal Nutrition (IJAN). Papers describing ruminant and non-ruminant research in specific areas are encouraged. The Journal is a place where peer-reviewed publications on basic and applied research can be shared. Priority is given to submissions that address the subject's new frontiers, such as growing fields of nutritional genomics, modeling, and interface themes such soil plant animal and ecosystem interrelationships. There are also reviews on specific themes. Since its beginning in 1983, the IJAN has been published quarterly under the auspices of the Animal Nutrition Society of India (ANSI), which has over a thousand life members around the world.

\section{OBJECTIVES OF THE STUDY}

The primary goal of this study is to examine the results of Indian Journal of Animal Nutrition research as expressed in the Indian Journals. Com publications from 2016 to 2020 . The study focuses in great detail on the following goals:

1) For the period 2016-2020, Indian Journals. Com was used to assess the whole spectrum of publications produced on animal nutrition research analysis.

2) Year wise distribution of publications.

3) Identify the highest article published authors.

4) Issue wise distribution of publications 


\section{METHODOLOGY}

The data for the three years (2016-2020) was retrieved from the Indian Journals Online database by searching for the keyword "Indian Journal of Animal Nutrition" in the title area. The Online database comprises 1985 to 2021 records in total.

\section{RESULTS AND ANALYSIS}

The data on animal nutrition research from the Indian journal database was analyzed and presented using a variety of statistical methods, including tables.

\subsection{IN ANIMAL NUTRITION RESEARCH OUTPUT FROM INDIAN JOURNAL DATABASE, GROWTH RATE AND DOUBLING TIME}

In the analysis of field research and development, a study of the growth rate of animal nutrition research production is critical. There are an identical number of publications on the relative growth rate of animal nutrition or study production over these years, as indicated in table -1 (1993 to 1996). Table 1 extracts and describes the quotes from the Relative Growth Rate [R9c) mean (0.19) and Doubling Time. The relative publishing growth rate fell and increased over the years specified, however the cumulative quantity of output [y] shows a progressive increase in Table 1. The doubling time [Dt(c)] increased from 2.57 to 173.3, with a three-year mean doubling time of 58.62 .

\begin{tabular}{|c|c|c|c|c|c|c|c|c|c|}
\hline Sl.No. & Year & $\begin{array}{c}\text { No. of } \\
\text { Publications }[x]\end{array}$ & $\begin{array}{c}\text { Cumulative } \\
\text { No. of } \\
\text { Output [y] }\end{array}$ & $\underset{x}{\log _{e} 1 y^{-}}$ & $\log _{e} 2 y-x$ & {$[R(c)]$} & $\begin{array}{l}\text { Mean } \\
{[R(c)]}\end{array}$ & {$[\operatorname{Dt}(\mathrm{C})]$} & $\begin{array}{c}\text { Mean } \\
{[\operatorname{Dt}(\mathrm{C})]}\end{array}$ \\
\hline 1 & 1985 & 51 & 51 & 0 & 3.93 & 3.93 & & 1.79 & \\
\hline 2 & 1986 & 56 & 107 & 3.93 & 4.02 & 0.09 & & 7.7 & \\
\hline 3 & 1987 & 61 & 168 & 4.02 & 4.11 & 0.09 & & 7.7 & \\
\hline 4 & 1988 & 68 & 236 & 4.11 & 4.21 & 0.1 & & 6.93 & \\
\hline 5 & 1989 & 74 & 310 & 4.21 & 4.3 & 0.09 & & 7.7 & \\
\hline 6 & 1990 & 75 & 385 & 4.3 & 4.31 & 0.01 & & 69.3 & \\
\hline 7 & 1991 & 77 & 462 & 4.31 & 4.34 & 0.03 & & 23.1 & \\
\hline 8 & 1992 & 61 & 523 & 4.34 & 4.11 & 0.23 & & 30.1 & \\
\hline 9 & 1993 & 56 & 579 & 4.11 & 4.02 & 0.09 & & 7.7 & \\
\hline 10 & 1994 & 56 & 635 & 4.02 & 4.02 & 0 & & 0 & \\
\hline 11 & 1995 & 57 & 692 & 4.02 & 4.04 & 0.02 & & 34.6 & \\
\hline 12 & 1996 & 57 & 749 & 4.04 & 4.04 & 0 & & 0 & \\
\hline 13 & 1997 & 66 & 815 & 4.04 & 4.18 & 0.14 & & 49.5 & \\
\hline 14 & 1998 & 77 & 892 & 4.18 & 4.34 & 0.16 & & 43.3 & \\
\hline 15 & 1999 & 83 & 975 & 4.34 & 4.41 & 0.07 & & 99 & \\
\hline 16 & 2000 & 78 & 1053 & 4.41 & 4.35 & 0.06 & & 115.5 & \\
\hline 17 & 2001 & 78 & 1131 & 4.35 & 4.35 & 0 & & 0 & \\
\hline 18 & 2002 & 62 & 1193 & 4.35 & 4.12 & 0.23 & 0.19 & 30.1 & 58.62 \\
\hline 19 & 2003 & 81 & 1274 & 4.12 & 4.39 & 0.27 & & 25.7 & \\
\hline 20 & 2004 & 72 & 1346 & 4.39 & 4.27 & 0.12 & & 57.7 & \\
\hline 21 & 2005 & 69 & 1415 & 4.27 & 4.23 & 0.04 & & 173.3 & \\
\hline 22 & 2006 & 64 & 1479 & 4.23 & 4.15 & 0.08 & & 86.6 & \\
\hline
\end{tabular}




\begin{tabular}{cccccccc}
23 & 2007 & 72 & 1551 & 4.15 & 4.27 & 0.12 & 57.7 \\
24 & 2008 & 58 & 1609 & 4.27 & 4.06 & 0.21 & 33 \\
25 & 2009 & 77 & 1686 & 4.06 & 4.34 & 0.28 & 24.7 \\
25 & 2010 & 78 & 1764 & 4.34 & 4.35 & 0.01 & 69.3 \\
26 & 2011 & 81 & 1845 & 4.35 & 4.39 & 0.04 & 173.3 \\
27 & 2012 & 80 & 1925 & 4.39 & 4.38 & 0.01 & 69.3 \\
28 & 2013 & 84 & 2009 & 4.38 & 4.43 & 0.05 & 138.6 \\
29 & 2014 & 79 & 2088 & 4.43 & 4.36 & 0.07 & 99 \\
30 & 2015 & 84 & 2172 & 4.36 & 4.43 & 0.07 & 173.3 \\
31 & 2016 & 88 & 2260 & 4.43 & 4.47 & 0.04 & 53.3 \\
\hline 32 & 2017 & 77 & 2337 & 4.47 & 4.34 & 0.13 & 69.3 \\
33 & 2018 & 76 & 2413 & 4.34 & 4.33 & 0.01 & 57.7 \\
34 & 2019 & 68 & 2481 & 4.33 & 4.21 & 0.12 & 115.5 \\
\hline 35 & 2020 & 64 & 2545 & 4.21 & 4.15 & 0.06 & \\
\hline Total & & 2545 & & & & & \\
\hline
\end{tabular}

\subsection{AUTHORS' HIGHEST ARTICLE}

The papers are divided into single, double, triple, multi-authored, and other categories to analyze the authorship pattern. The number of publications in each category is counted, and the percentage is calculated to reflect research trends as solo or collaborative research in a specific topic. Table 4.2 shows that for the year, around 2545 papers were submitted by many authors (1985 to 2020). Out of 2545 publications, the most were published by more than two authors, accounting for 170 (6.67\%), followed by three-authored articles accounting for 44 (1.72\%). Four writers contributed 21 publications, accounting for 0.82 percent of the total. Six writers authored 9 publications, accounting for 0.35 percent of the total. Seven to a single author published 0.27 percent to 0.03 percent of publications. However, the author pattern in the publication indicates that there were more than fifteen authors on the team.

\begin{tabular}{|c|c|c|c|c|c|c|c|c|c|c|c|c|}
\hline $\begin{array}{c}\text { Number of } \\
\text { Authors }\end{array}$ & 2 & 3 & 4 & 5 & 6 & 7 & 8 & 9 & 10 & 11 & 12 & 15 \\
\hline $\begin{array}{c}\text { Number of } \\
\text { Paper }\end{array}$ & $\begin{array}{c}170 \\
(6.67 \%)\end{array}$ & $\begin{array}{c}44 \\
1.72 \%\end{array}$ & $\begin{array}{c}21 \\
0.82 \%)\end{array}$ & $\begin{array}{c}17 \\
(0.66 \%)\end{array}$ & $\begin{array}{c}9 \\
(0.35 \%)\end{array}$ & $\begin{array}{c}7 \\
(0.27 \%)\end{array}$ & $\begin{array}{c}3 \\
(0.11 \%)\end{array}$ & $\begin{array}{c}1 \\
(0.03 \%)\end{array}$ & $\begin{array}{c}4 \\
(0.15 \%)\end{array}$ & $\begin{array}{c}1 \\
(0.03 \%)\end{array}$ & $\begin{array}{c}1 \\
(0.03 \%)\end{array}$ & $\begin{array}{c}1 \\
(0.03 \%)\end{array}$ \\
\hline
\end{tabular}

\subsection{ISSUE-BASED PUBLICATION DISTRIBUTIONS}

Contributions to five online quarterly Indian journals in the field of animal nutrition, published by various academics, were issued in four issues per volume, which were examined for the study from 2016 to 2020 . The table illustrates the fiveyear durations that were taken into consideration.

\begin{tabular}{|cccccc}
\hline \multicolumn{5}{c}{ Table 3 Issue-Based Distributions } \\
\hline Year & Number of Issue & & & & Total (\%) \\
\hline & 1 & 2 & 3 & 4 & \\
\hline 2016 & 24 & 21 & 23 & 20 & $88(6.44)$ \\
\hline 2017 & 19 & 18 & 19 & 21 & $77(3.02)$ \\
\hline 2018 & 20 & 19 & 19 & 18 & $76(2.98)$ \\
\hline 2019 & 15 & 17 & 17 & 19 & $68(2.67)$ \\
\hline 2020 & 16 & 17 & 16 & 15 & $64(2.51)$ \\
\hline
\end{tabular}




\section{CONCLUSION}

Contributions are made to online quarterly Indian journals in the subject of animal nutrition. The biggest number of articles were published in 2016, with 88 (3.45\%), and the lowest number of articles were published in 1985, with 51 (2.00\%). In the years 2019 and 2020, "Issue Number 1 and 4" published articles in the highest 24 (09.20 percent) articles and the least number of articles 15 (7.63\%). The most papers were published by more than two authors, accounting for 170 in total $(6.67 \%)$.

\section{REFERENCES}

Adarsh Bala and Gupta B.M (2012). Measles: A Quantitative Analysis of World Publications during 2001 - 2010. Journal of Scientometric Research, Vol.1(1), pp.60-70. Retrieved from https://doi.org/10.5530/jscires.2012.1.11

Chaoyang Liu (2020). A Scientometric Analysis and Visualization of Research on Parkinson's Disease Associated with Pesticide Exposure. Front. Public Health, $07 \quad$ April 2020. Retrieved from https://doi.org/10.3389/fpubh.2020.00091

Grant Lewison et al. (2021). Cancer Research in Latin America 2014-2019 and its disease burden. Journal of Scientometric Research, Vol.10(1), pp.21-31. Retrieved from https://doi.org/10.5530/jscires.10.1s.19

Illya Martynov, Jessica Klima-Frysch and Koachim Schoenberger (2020). A Scientometric Analysis of Neuroblastoma Research. BMC Cancer, Vol.20 Article No.486. Retrieved from https://doi.org/10.1186/s12885-02006974-3

Jisha Antomy and Raja Selvaraju (2019). Growth, Indexing and Authorship Pattern of Poultry Industry Research Publications. Journal of Scientometric Research, Vol.8(3), pp.150-155. Retrieved from https://doi.org/10.5530/jscires.8.3.31

Rajendran L (2021). Cab direct is the focus of a scientometric analysis from 2011 to 2013: beans scientific research articles. International Journal of ResearchGRANTHAALAYAM, Vol..9(8). pp.35-41. Retrieved from https://doi.org/10.29121/granthaalayah.v9.i8.2021.4135

Rajendran L (2021). Wheat scientific research articles from 2011 to 2013: cab direct is the focus of a scientometric analysis. International Journal of Research and Analytical Reviews, Vol.8(3), pp.778-785.

Seyyed Mehd Hosseini Jenab (2014). Evaluation of the Scientific Production of Countries by a Resource-Scaled Two-Dimensional Approach. Journal of Scientometric Research, Vol.3(3), pp.95-103. Retrieved from https://doi.org/10.4103/2320-0057.153550 


\section{ABOUT THE AUTHOR}

Dr.L. Rajendran is working as an Assistant Librarian in the Department of Library Science, Madras Veterinary College, TANUVAS, Chennai. He has completed a Master degree in M.K.University in 1993; he finished his M.Phil in 2003 from Alagappa University and Ph.D in 2008 from M.S.University. He has 23 years of experience in the field of Library and Information Science. He has published 111 research papers in different journals, conference and seminar proceedings and published 5 books in the field of library and information science. He has organised a number of training workshops, seminars and conferences in Library and Information Science. He is a life member of various International and National Associations. He has completed a World Bank funded research project "Strengthening of Digital Library and Information Management under NARS (e-Granth) and another project is "National Knowledge Management Centre for Agriculture Education and Research" funded under NAHEP. His research interests are Information Communication Technology (ICT), Digital Library, User Studies, Library Management, Scientometrics and Bibliometrics 